\title{
Rural Housing in Iran: Past, Present, and Future
}

\author{
Mohsen Sartipipour
}

Department of Architecture, School of Architecture \& Urbanism, Shahid Beheshti University, G.C., Tehran, 1983963113, I.R. IRAN

\begin{abstract}
This research was carried out using a descriptive-analytical method based on data from 2003 sampling of the Rural Housing in Iran, library studies, and historical documents and researches. The first part is allocated to an introduction of the necessities of considering rural housing. The second part deals with the current status of rural housing in Iran. In this part, we will discuss the current status of rural housing in Iran from four aspects, namely, fabric, accessibility to welfare facilities, the role of livelihood activities in housing, and environmental dimension at provincial levels. The final part based on the data obtained from Census 2003 and the result of a study of features of vernacular rural housing, adopting a regional approach for provision of rural housing appropriate for the condition of each province has been suggested as the most important priority and requirement in the system of housing programming.
\end{abstract}

Keywords Iran, Iran's villages, rural housing, housing needs, regional approach

\section{Introduction}

Although in recent decades investments in rural areas have been insignificant in comparison with urban areas in Iran, rural areas are still considered to be the hubs for creation of wealth and economic added-value in agriculture, livestock, and handicraft sectors. Rural areas were best option for provision of required food, being responsible for one-third of Iran's gross national product (GNP) till three decades ago. (Taleb 1998) According to the latest National Population and Housing Census in 2006 over 22.235 million of the whole 70.495 Iranians live in rural areas. (SCI 2006) This census also states that 5.096 million of the 14.9 million Iranian households live in villages and the number of rural settlements in Iran is 4.42 millions most of which are in poor conditions (MHUD 2006, 14). The excessive poor quality of the houses in terms of structure and some shortcomings such as unhealthy and unclean living conditions of the houses involved in working spaces has convinced the government to set an agenda for planning, policy-making and taking appropriate measures towards provision of appropriate rural settlements ${ }^{1}$. Since the Iranian government is obliged to

* Corresponding author:

m-sartipi@sbu.ac.ir (Mohsen Sartipipour)

Published online at http://journal.sapub.org/arch

Copyright (C) 2012 Scientific \& Academic Publishing. All Rights Reserved

\footnotetext{
${ }^{1}$ Detailed analysis of the results of 2006 National Census shows that 22.3 million villagers of Iran are living in 63898 villages. $42 \%$ of these settlements (28271 villages) have a population of less than 100 people totally amount to 1 million. This population, residing in less than half of Iranian villages $(42 \%)$, covers just $5.6 \%$ of the total rural society. Villages containing $100-500$ people are 23855 hosting 5.74 million people. About 10.746 million people are living in 10699 villages populating 500-2499 people and 4.63 million people live in 1043 villages having a population of more than 2500 .
}

support renovation or construction of 200000 rural residential units per year (Sartipipour 2007a) according to Fourth Social, Cultural and Economic Development Plan of Iran (2005- 2009), the renovating trend of rural houses boomed and 620000 new residential units were built during 2006-2008 alone.(HFIRI 2008, HFIRI 2009)

Housing is the major element forming the rural context and its spatial arrangement, and deployment and construction style represent the use of environmental elements and the effects of economy, livelihood, traditions and norms on the rural community. Considering that rural housing provides the context for living and livelihood activities for villagers which has a functional nature for them to meet their basic needs, entering this realm requires a vast knowledge and awareness of all dimensions of design and formation. (HFIRI 2005) It can be stated that providing proper housing for villagers can be accomplished only when recent socioeconomic changes, modern technologies and facilities corresponding to the features of vernacular rural architecture and tribal-cultural traditions of villages and various climatic conditions of different regions are taken into account. Undergoing informed transformations in rural architecture and making decisions for the future requires understanding these features in the past and present.

\section{Rural Housing in the Past}

A general and comprehensive view of housing from the past to the present shows that housing is a social, cultural, economic and structural phenomenon which provides the proper livelihood conditions. (Zargar 1999) Living environment ancient times are only examples of this fact. The human being has had a continuous long-lasting relationship with his residential space involving all his life from birth to death. 
Represents a typical predefined pattern in the world of causes The generation and formation of rural housing in Iran has a long standing, the roots of which could be traced back in the historical generation and formation of villages. However, alongside this housing, there has always been another kind of housing based on tribal life which was aimed at raising livestock. (Sartipipour 2009) This kind of housing has led to formation of tribal communities which is still seen in some areas of the country. The contingencies of tribal life necessitates a particular type of settlement characterized by mobility and quick setup, which leads to different movable housing structures such as tents ${ }^{\mathrm{i}}$ and bowers ${ }^{\mathrm{ii}}$.(Figure 1)

However, villages are the first forms of settlement in Iran that appeared 40 centuries B.C. in Zagros slopes in Western Iran (Northern Khuzestan areas) through the abundance of water and fertility of lands. However, in other areas of Iran, including Alborz slopes, the Central, Southern and Eastern Iran, signs of existence of primitive villages can be found. With the formation of villages and promotion of agriculture and ideals of human beings and people have always been striving throughout the history to achieve those causes and ideals. (Zargar 1997) The experiences of our ancestors and evolution of different housing patterns inherited from the significant changes emerged in the livelihood and social trends and there was a need for setting up a house for people and the families near the farmlands. Since then, livelihood through farming as a source of providing crops and livestock products, and using livestock for running the daily affairs have influenced the housing design and structure.

A brief review of the general characteristics of the rural architecture in Iran shows that geographical and climatic conditions along with livelihood styles has affected rural housing in a way that can be considered as the reflection of various livelihood styles, lands, and economical social and cultural factors. So it could be said that this environment provides the required place for living, working, storing goods and farm products, animal husbandry, etc. Therefore, it enjoys various patterns. In all of these patterns, the application of natural resources and the limitations it imposes have been reflected. Due to the special geographical, economical and social systems that are the results of a process of trial and error during the history, different residential units could be seen all over Iran in different condensed or non-condensed textures, with symmetrical and asymmetrical architectural plans some of which seemingly do not follow any patterns.

Studying vernacular rural residential units shows four general patterns with quite distinctive features: (Sartipipour 2009)

(1). Northern areas alongside the Caspian Sea

(2). Alborz and Zagros slopes

(3). Central Iran (areas bordering with Dasht-e Kavir and the Persian Gulf); and

(4). Persian Gulf and Sea of Oman in the South.

\subsection{Northern Areas alongside the Caspian Sea}

In Northern Areas alongside the Caspian Sea (Northern Iran), abundance of water and fertile soil for farming has caused villages to have a scattered pattern. Moreover, area of residential plots is relatively high and residential environments are surrounded with citrus fruits. Native people of these areas used to make a living by farming, gardening, working on rice fields, and fishing. Not long ago, houses were made of wood and then thatched with clay and straw. Ceilings were covered with Sufal (made of baked clay), canes or stems of rice plant. Dense forests on the margins of the Caspian Sea and mountains provide the wood needed for making houses. Ceilings, pillars and in some cases, walls and the foundations of houses were made out of wood. (Figure 2)

Where the land moisture is high, the house floor is built above the ground level.

\subsection{Alborz and Zagros Slopes}

Mountain slopes of Alborz and Zagros mountain ranges are the seat of most of the cities and villages of Iran. Houses mostly are two-storey buildings and include a drawing room for entertaining visitors which enjoys a better condition in comparison to other rooms and has a separate entrance. In two-storey houses, the drawing room is on the second floor of the house with several openings to provide lighting and a proper perspective for the visitor. In these houses, the first floor are used as a place for keeping livestock, stable, store house, kitchen, and the second floor are designed as living spaces like the living-room and drawing room. (Figure 3)

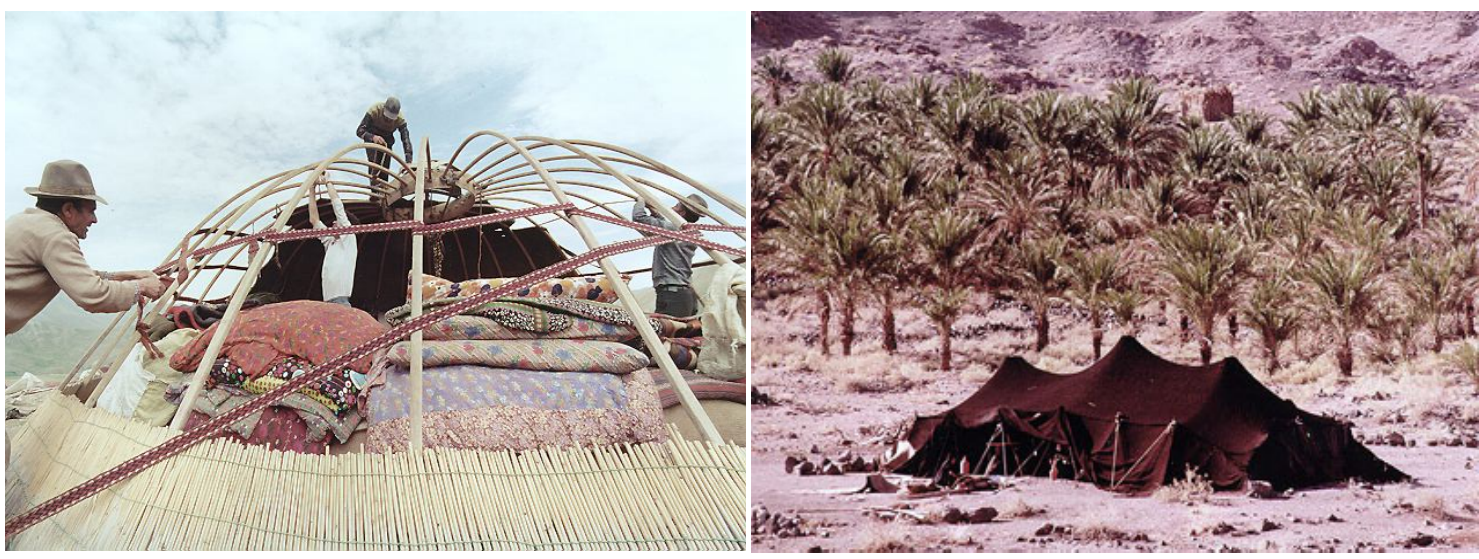

Figure 1. Examples of Tribal Settlement Left: a Bower in Western Iran. Right: Black-tents of Southern Iran 

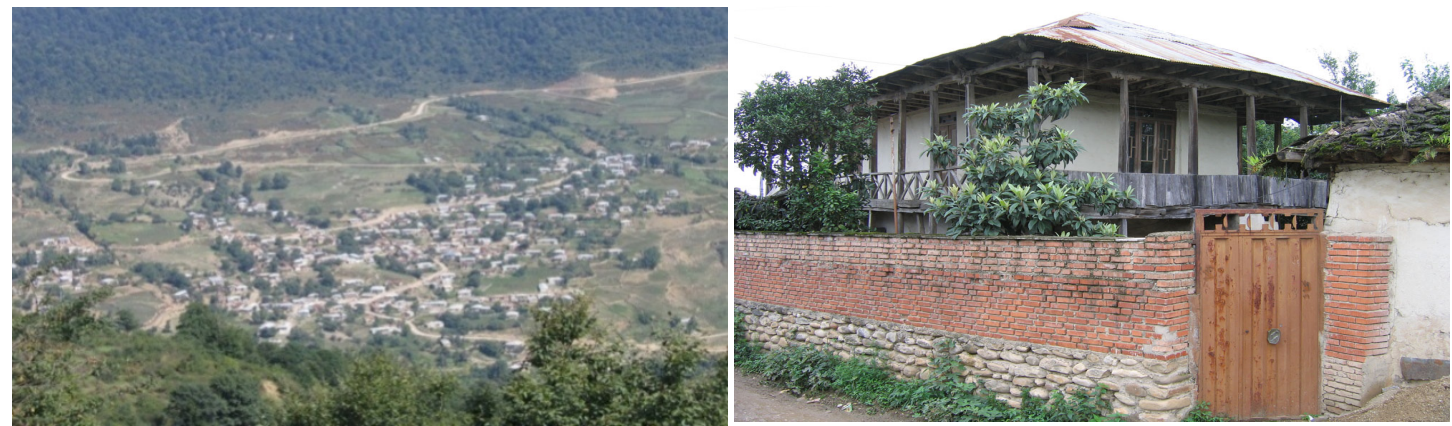

Figure 2. Examples of Rural Housing and Context in Northern Iran
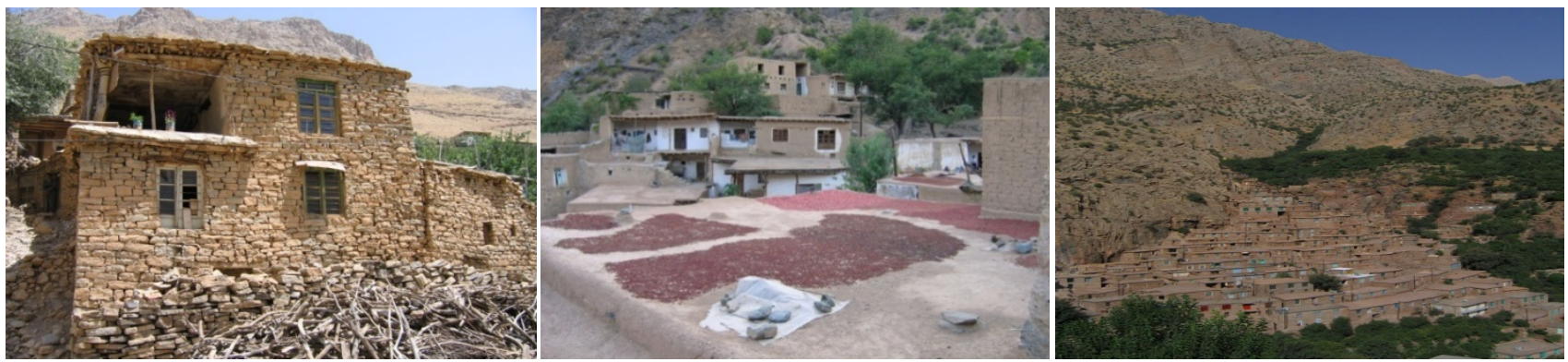

Figure 3. Examples of Rural Housing and Context in Western Iran (combining livelihood space with residential space: use of rooftops as a place for making dried fruits is seen the middle picture)

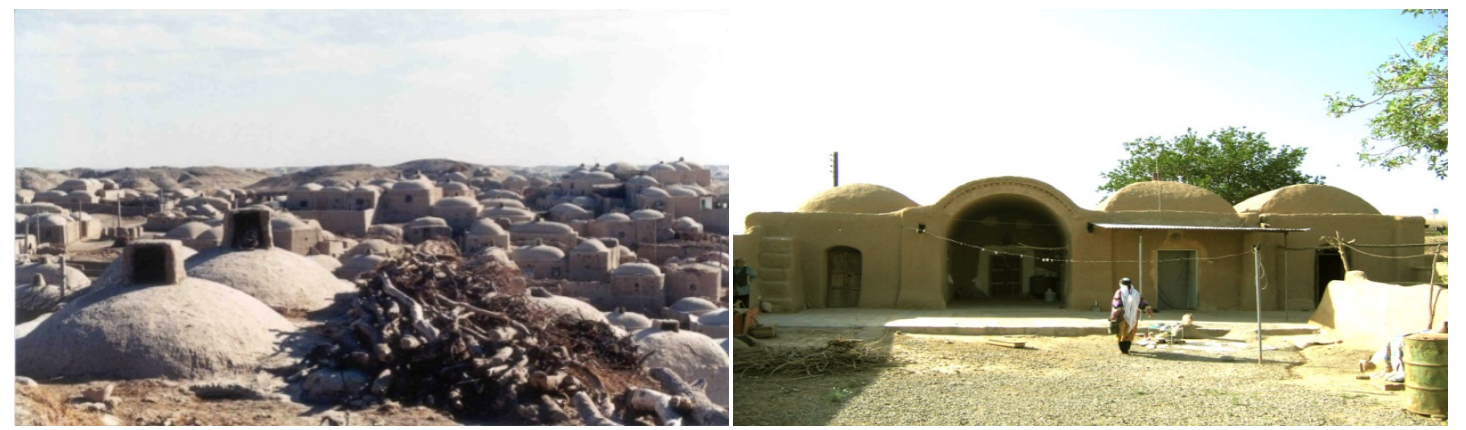

Figure 4. Examples of Rural Housing and Context in the Desert Areas of Iran

\subsection{Central Iran}

Central Iran is an arid salt desert with a harsh nature and an average annual precipitation of less than $200 \mathrm{~mm}$. Living in these areas is only possible around or near Qanats (aqueducts) and springs. Aqueducts are sustainable subterranean systems for drawing the underground water resources to the surface which is the result of a genuine Iranian irrigation innovation that slowly draws the underground water to the surface and has supplied water for thousands of years. Shortage of water in this region has made aqueducts an invaluable element such that not a drop of water is wasted. Whenever the amount of water is not adequate, it is first directed into a pool and then drawn into the farms. The size of the villages and their population in this region are determined by the amount of water available.(figure 5)

Clay and sun-dried clay are the basic materials for housing in desert areas in Iran. Houses were built very close to each other in a dense context. Applying clay which is resistant to heat made living through hot summers possible. Houses are introvert and with the courtyard placed in the center (central courtyard pattern) to protect the house from the harsh nature and hot winds as well as provide the dwellers with an appropriate open space. Rooms are separate units and open to the courtyard. In complete harmony with seasonal changes and in order to provide dwellers with comfort inside the house, some movements are necessary for the family members from the sunny parts of the house (suitable for the winter) to the parts back to the sun and shaded parts (suitable for the summer). The family members move upstairs, downstairs, and to the north or to the south Eyvans (porches) of the house.

\subsection{Persian Gulf and Sea of Oman in the South}

Villagers living on the margins of the Persian Gulf and Sea of Oman (Southern Iran) have made a living by fishing, cultivating palm trees, doing businesses and transporting goods to the Persian Gulf Countries. Hot and humid weather and lack of drinking water has resulted in a particular living pattern with a form quite different from other regions of Iran. In order to ease the air flow and to reduce the relatively high humidity, villages have scattered textures so that coast breezes will easily flow in the atmosphere. This has also affected the design of the house; houses are built in a way so 
that wind can flow easily inside them. That's why windows are designed on both sides of the house letting air flow inside the house to provide comfort for the dwellers. Most houses in this region have wind-catchers to benefit from the breezes coming from the sea. In order to reduce heat absorption and enhance sunlight reflection, the color of the house is bright. Moreover, the houses are designed in a way so that the walls are not directly exposed to sunlight and provide shade. (Figure 5)

In all of the cases discussed above, rural residential units, while featuring simplicity and plainness, make use of architecture style appropriate to livelihood functions and natural environments, and every region follows a special aesthetic and visual pattern which differentiates it from other regions through its particular use of materials and vernacular housing knowledge.

\section{Rural Housing Today}

This section of the paper is based on assessment and evaluation of the data from the sampling of rural housing features in 2003, implemented for the first time in the history of housing planning in Iran in 2118 sample villages, through which the structural and housing features of 46413 houses were collected throughout the country.(HFIRI, 2003) The analysis of the quantitative and qualitative data from this sampling, which was carried out by the Faculty of Architecture and Urbanization of Shahid Beheshti University, is so far the most important and up-to-date source of information about the current status of rural housing which can provide the required data for rural housing. ${ }^{2}$

Due to the large amount of sampling data collected, adopting a proper technique for summarizing and interpreting the data was necessary. For this reason, related data were classified using the grounded theory method (a qualitative method). Then, the whole data, presented in 91 tables, was classified and encoded at four levels, from micro to macro and titled as: indicator ${ }^{3}$ level one, indicator level two, index level ${ }^{4}$, and dimension level ${ }^{5}$. (Sartipipour, 2007) In this wa y, through selecting two or more related data ${ }^{6}$ and combining them, a higher level terminology is achieved which is called level-one indicator. Combining two or more level-one indi-

\footnotetext{
${ }^{2}$ An attempt made to detect similar studies in other countries in order to use their experience failed to produce any results.

3 An indicator refers to data produced through combining and integrating two or more set of data in a more comprehensive way. Here, indicators are classified in two types: indicator level one and indicator level two)

${ }^{4}$ After determining indicators, an integrative set of indicators is achieved which can present a more comprehensive concept of housing features. An index refers to the level of data produced through combining and integrating two or more indicators.

${ }^{5}$ After editing and modifying data, indicators and indexes are produced through combining indexes related to major dimensions influencing housing. The results of combining and integrating indexes are summarized as four main dimensions including physical structure, economy and livelihood, welfare, and environment, subjects that represent the quality of housing.

${ }^{6}$ Data is the smallest level of information in this study that cannot be divided into smaller parts. In fact, data are information achieved immediately after sampling.
}

cators produces a more comprehensive indicator called level-two indicator. In the next step, we combined level-two indicators which resulted in a higher level of information called index level. In the next step, the combination of axial indexes produced a more comprehensive level of housing information in four dimensions of fabric, economy and livelihood, welfare, and energy and environment. Finally, through synthesis and combining of four dimensions of housing features, the current status of rural housing at national and provincial levels was determined, which can be used for future planning and decision-makings.(Sartipipour 2007)

As mentioned before, the basis of this analysis is the "data, indicator, index, and four dimensions" levels of information, with the housing status as the highest level (See Figure 6). When the four dimensions of rural housing are determined, the quantitative and qualitative information thus obtained could be used in future housing schemes.

In order to determine the current status of housing in different provinces and making comparison between them possible, the Delphi method was used. For this purpose about twenty experts in the field of rural housing and architecture in Iran were consulted and the weights of the indicators were determined. (Sartipipour 2007) Based on the effectiveness and level of importance of each indicator, they were weighed from 0 to 100. The housing status in the country was determined on the basis of how each indicator was weighed in each province. To compare the housing status of the provinces, those provinces with mean indicators above 70 were classified as group one (Good), and between 70 and 50 as group two (Average), between 40 and 50 as group three (Below average), and below 40 as group four (Weak). (Sartipipour 2007) Based on definitions presented above and the analysis done, the current status of rural housing is discussed below under four dimensions of fabric, economy, welfare, and environment:

\subsection{Fabric Dimension of Rural Housing}

Fabric dimension of housing refers to its physical aspect which is the most objective aspect in assessment, analyzing and planning of housing. Most planning and analyses in housing usually focus on this aspect.

From the fabric point of view, rural housing is studied on the basis of two indexes including "strengths" (that involves foundation, ceiling, walls and the like), which is the basis of the stability of the building, and "dwelling areas" like rooms, floors and the floor area.

In examining the data from the samples, the "strength" factor was evaluated under three level-one indicators: durability of materials, durability of structure, and the oldness of the house. When combined together, these three indicators determine the "strength of rural houses" (See Table 1). As it was mentioned before, every indicator in level one is composed of few lower level indicators (level two) and every level-two indicator is made up of some data from the sampling questionnaires. 

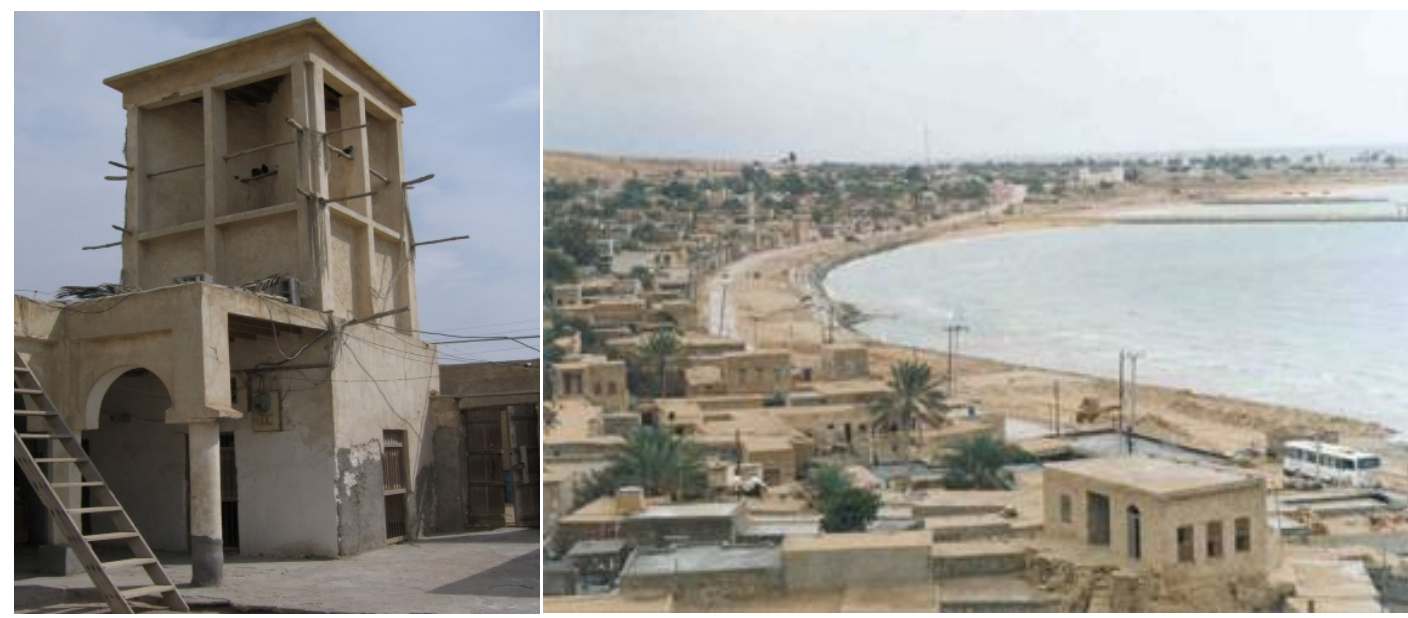

Figure 5. Examples of Rural Housing and Context in Southern Iran, Left: Wind-catchers in Residential Units to Make Use of Coastal Breeze. Right: Settlements on the Margins of Persian Gulf

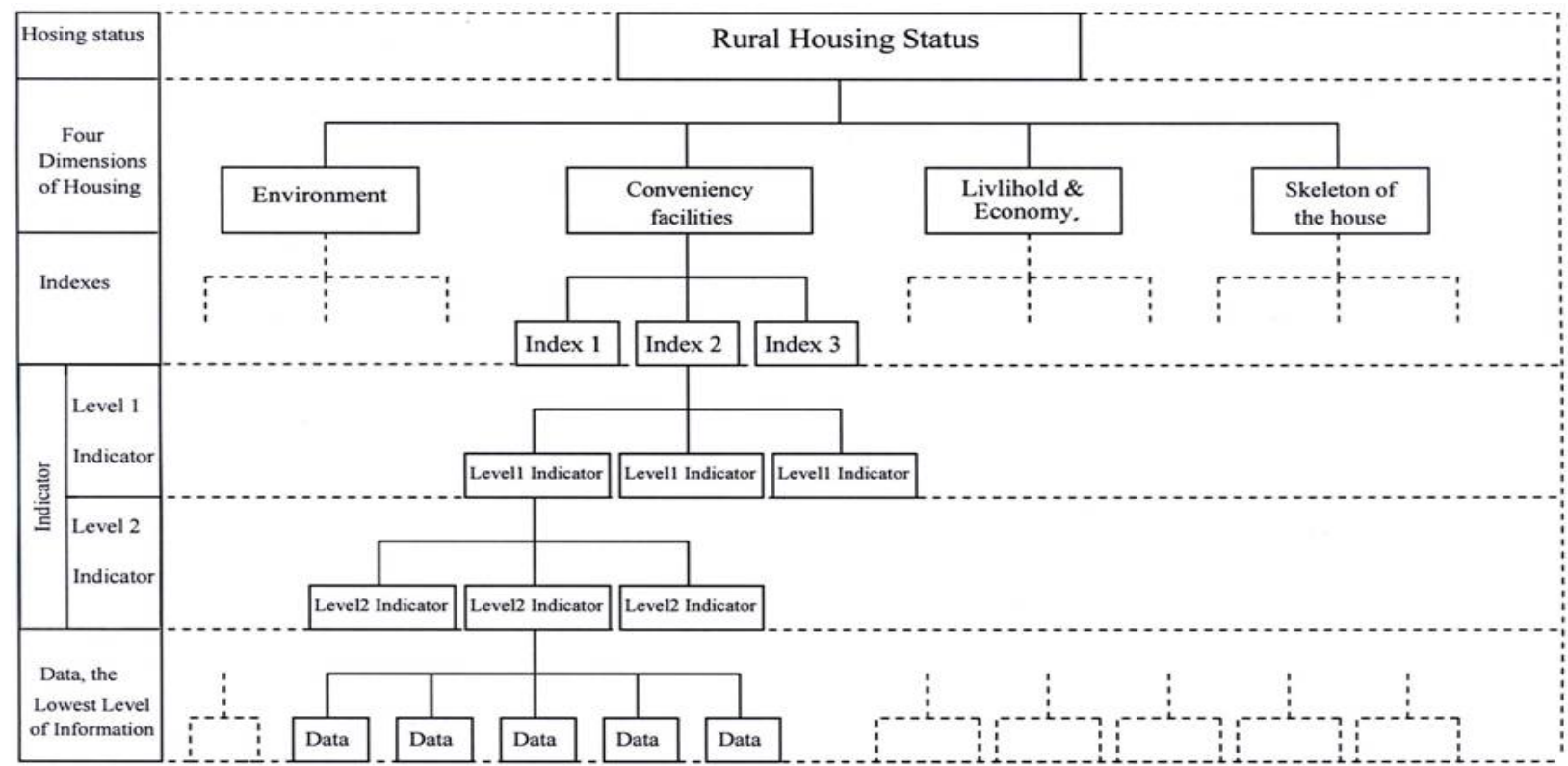

Figure 6. Schematic Model of Rating the Levels the Data of the Questionnaire to Higher Levels of Information and Determining the Current Housing Status

For determining the indicator of "dwelling areas of the residential units" and assessing the available or occupied areas, three level-two indicators, namely room density, number of floors, and the floor area were used. (Sartipipour 2007)

Using the technique for determining weight of indicators and indexes, and as a result of comparative study of dimensions in provinces, four provinces fall into the first group, nine provinces lay in the second group, 14 provinces stand in the third group, and one province goes to the fourth group. To see the fabric status of rural housing, groupings ${ }^{7}$ were specified on the map and some zoning were found at four different levels in a geographical distribution (see figure 7)

\footnotetext{
${ }^{7}$ It must be noted that grouping and grading provinces based on information and data recorded in sampling questionnaires of rural housing features, is the result of a study in 2003. The validity of this sampling was verified through the letter no. 27/2849, dated: 2006/04/23) from Bureau of Infrastructural Statistics, Statistics Center of Iran.
}

\subsection{Economy and Livelihood Dimension of Rural Housing}

The combination of the livelihood and environment in rural houses and the effects of investment in this sector is another important aspect which should not be ignored $f$ we want to present a comprehensive picture of the current rural housing. Probably, the most fundamental difference between urban and rural housing is that in villages, livelihood and production activities are mixed with daily activities. Therefore, within the context of studying the current status of rural housing, attending to this sector and the role of investment in this sector in the rural economy and national economy is of great importance. Since part of the livelihood and producing activities of villagers is done in residential 3 units, livelihood and living activities are somehow combined. Due to production activities in rural houses and the mutual relationship between livelihood and living activities, settlements have turned into spaces with different functions including liveli- 
hood, mixed livelihood and living, featuring architecture distinctive from typical living spaces. On the other hand, considering macro-economy, the amount of national investment in providing rural housing can affect not only the employment rate in rural areas, the supply and demand market of land, materials and housing, but also the quantity and quality of the development of villages. Although widespread economical study in this area requires existence of precise economical data and indices which are beyond the scopes of our sampling in 2004, attempt was made to consider this dimension based on other available data. The above mentioned cases were studied under the title of "economy and livelihood in rural housing" with five indexes.

The index of "the role of livelihood in housing" was analyzed using indicators level one and two (a sub-set of parts and spaces and the amount of areas allocated for livelihood). The bigger this index, the higher the role of economical and livelihood activities of families in housing would become. The other index examines the status of livelihood spaces in terms of physical quality (level of strength and sanitation). The higher this index, the higher the possibility of livelihood activities in the residential units would be.

Therefore, the status of living spaces in rural houses was studied using these two indexes.

However, the effects of housing on economical development were analyzed and measured using three indexes of the ability to afford housing expenses, flourishing rate of land and house market, and productivity and effectiveness in this sector. Table 2 shows all level one and two indicators related to these indexes. (Sartipipour 2007)

The result of the comparative survey of the provinces shows that six provinces fall into the first group, 10 provinces into the second group, nine provinces into the third group, and three provinces into the fourth group. Figure 8 indicates the status of rural housing in the provinces of Iran in terms of economy and livelihood.

\subsection{Welfare Dimension of Rural Housing}

Availability of proper infrastructural welfare facilities and services in rural societies is a fundamental basis of development which is aimed at proportionate distribution of livelihood facilities and decreasing inequalities. In recent dec- ades, establishing infrastructural facilities and providing people with cultural and health services has been the theoretical and practical foundation of many development programs. As a result, one of the major objectives of rural development has been the equal distribution of the above mentioned facilities and increasing availability of these services to villagers. Therefore, studying the type and amount of welfare facilities in rural residential units is another important aspect that determines the quality of rural life and rural housing.

To study the welfare status of rural housing, the welfare facilities and infrastructural services such as running water, power, telephone, sewage disposal systems, and availability of services like education, health and commercial environments were considered and analyzed. Two indexes were analyzed using a set of level-one and level-two indicators (See Table 3), the two indexes were: the availability of housing (since it provides the context for family life) and availability of the welfare facilities in the village (since it provides the context for the residential units). (Sartipipour 2007)

According to the results of analysis of this dimension of rural housing, three provinces fall into the first group, 12 provinces in the second group, eight provinces in the third group and five provinces in the fourth group. Geographical distribution of welfare in residential units is shown in figure 9.

\subsection{Environmental Dimension of Rural Housing}

Today, in many countries, developmental activities and initiatives are subject to environmental conservation and prevention of environmental pollution, avoidance of destruction of farmlands and natural resources and changing their use. In other words, the environmental status of a country is one of the most important criteria of labeling it as a developed society. Considering the effects of construction and building activities on rural nature and environment, studying this dimension of housing is required. The environmental dimension of housing is measured through two indexes, namely, the effect of residential units on destruction of ecosystems, and compatibility of residential units to nature and the environment.

Table 1. Indexes, level one \& two Indicators of the Housing Fabric Dimension and the Relation between Levels

\begin{tabular}{|c|c|c|c|}
\hline Dimension & Index & Level one indicators & Level two indicators \\
\hline \multirow{12}{*}{$\begin{array}{l}\text { Fabric Di- } \\
\text { mension of } \\
\text { Rural } \\
\text { Housing }\end{array}$} & \multirow{9}{*}{$\begin{array}{l}\text { The strength of } \\
\text { Residential Units }\end{array}$} & \multirow{5}{*}{$\begin{array}{l}\text { Durability of Materials Used } \\
\text { in Residential Units }\end{array}$} & The Durability of Materials Used in Foundation of Residential Units \\
\hline & & & The Durability of Materials Used in Walls of Residential Units \\
\hline & & & The Durability of Materials Used in the Footing of Residential Units \\
\hline & & & The Durability of Materials used in Ceiling of Residential Units \\
\hline & & & The Durability of Materials Used in the Floor of Residential Units \\
\hline & & \multirow{3}{*}{$\begin{array}{l}\text { Durability of the Structure } \\
\text { of Residential Units }\end{array}$} & The Durability of the Skeleton of Residential Units \\
\hline & & & The durability of the Ceiling structure of Residential Units \\
\hline & & & Earthquake Resistance Facilities of Residential Units \\
\hline & & Age of Residential Units & Average Age of Residential Units \\
\hline & \multirow{3}{*}{$\begin{array}{l}\text { Dwelling Areas of } \\
\text { Residential Units }\end{array}$} & \multirow{3}{*}{-------- } & Room Density in Residential Units \\
\hline & & & Floor Density in Residential Units \\
\hline & & & Floor Area \\
\hline
\end{tabular}




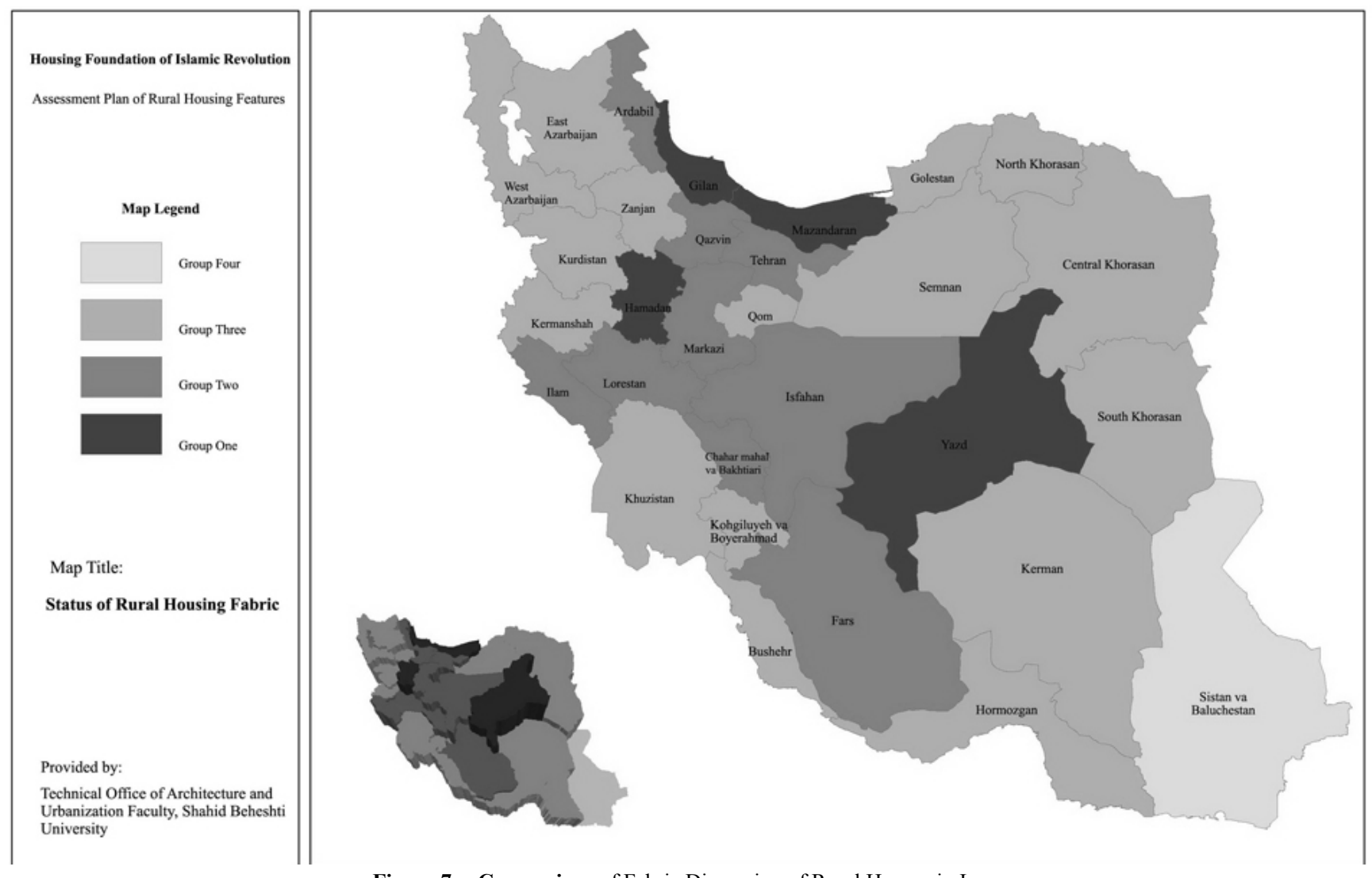

Figure 7. Comparison of Fabric Dimension of Rural Houses in Iran

Table 2. Indexes, level one \& two Indicators of the Economy Dimension of Rural Housing and the Relationship between Different Levels of Analyzing in a Hierarchical Structure

\begin{tabular}{|c|c|c|c|}
\hline Dimension & Index & Level one indicator & Level two indicator \\
\hline \multirow{32}{*}{$\begin{array}{l}\text { The Economy of } \\
\text { Dimension of } \\
\text { Rural Housing }\end{array}$} & \multirow{4}{*}{$\begin{array}{l}\text { Role of Housing } \\
\text { in Livelihood }\end{array}$} & \multirow{2}{*}{$\begin{array}{c}\text { Using Residential Units for } \\
\text { Livelihood }\end{array}$} & Use of Different Parts of the House for Livelihood Functions \\
\hline & & & Percentage of Residential Units Having Livelihood Spaces \\
\hline & & \multirow{2}{*}{$\begin{array}{c}\text { Area Dedicated to Livelihood } \\
\text { Space }\end{array}$} & Proportion of the Floor Area Dedicated to Livelihood Space \\
\hline & & & Average Area Dedicated to Livelihood Space \\
\hline & \multirow{8}{*}{$\begin{array}{l}\text { Strength of Live- } \\
\text { lihood Spaces in } \\
\text { Rural Residential } \\
\text { Units }\end{array}$} & \multirow{4}{*}{$\begin{array}{c}\text { Durability of Materials Used in } \\
\text { Livelihood Spaces }\end{array}$} & The Durability of Materials Used in the Foundation of Livelihood Space \\
\hline & & & The Durability of Materials Used in the Walls of Livelihood Space \\
\hline & & & The Durability of Materials Used in the Footing of the Livelihood Space \\
\hline & & & The Durability of Materials Used in the Ceilings of Livelihood Space \\
\hline & & \multirow{3}{*}{$\begin{array}{l}\text { Durability of Structures Ap- } \\
\text { plied in Living Spaces }\end{array}$} & The Durability of Skeleton Used for Livelihood Space \\
\hline & & & The Durability of Ceiling Structure Used for Livelihood Space \\
\hline & & & Earthquake Resistance Facilities of the Livelihood Space \\
\hline & & Age of the Residential Units & Average Age of the Livelihood Space \\
\hline & \multirow{8}{*}{$\begin{array}{l}\text { Ability to Afford } \\
\text { Housing Expenses }\end{array}$} & \multirow{3}{*}{$\begin{array}{l}\text { Ability to Afford Current Costs } \\
\text { of Residential Units }\end{array}$} & The Share of Current Costs out of Family Income \\
\hline & & & Average Number of Family Members in the Residential Units \\
\hline & & & Ability to Afford the Expenses of Occupying the House \\
\hline & & \multirow{3}{*}{$\begin{array}{c}\text { Ability to Afford Fixed Costs of } \\
\text { Housing Unit }\end{array}$} & Ability to Afford the Expenses of Fundamental House Repairs \\
\hline & & & Ability to Afford the Costs of Buying a House \\
\hline & & & Ability to Afford the Costs of Building a House \\
\hline & & \multirow{2}{*}{$\begin{array}{c}\text { Amount of the Use Financial } \\
\text { Aids to Provide for Housing } \\
\text { Expenses }\end{array}$} & Using House Procurement Loans for Building or Basic Repairs \\
\hline & & & Use of Non-Reimbursable Aids for Building or Basic Repairs \\
\hline & \multirow{6}{*}{$\begin{array}{l}\text { Prosperity of Land } \\
\& \text { House Market }\end{array}$} & \multirow{3}{*}{$\begin{array}{l}\text { Effect of Employment in Pros- } \\
\text { perity of Land \& House Market } \\
\text { Supply Rate of Proper Housing }\end{array}$} & Skillfulness of Work Force Engaged in House Construction \\
\hline & & & The Proportion of Native People in House Construction \\
\hline & & & Rate of Constructing New Houses \\
\hline & & \multirow{3}{*}{ Effective Housing Demand } & Demand for Houses and Lands \\
\hline & & & Ability to Afford the Costs of Building a House \\
\hline & & & Ability to Afford the Costs of Buying a House \\
\hline & \multirow{6}{*}{$\begin{array}{l}\text { Productivity of } \\
\text { rural housing }\end{array}$} & \multirow{4}{*}{$\begin{array}{l}\text { Productivity in House Con- } \\
\text { struction }\end{array}$} & Time Productivity in Construction \\
\hline & & & Productivity of Level of Workforce Engaged in House Construction \\
\hline & & & Productivity of Materials Used for Production of in House Construction \\
\hline & & & Use of Technology in House Construction \\
\hline & & \multirow{2}{*}{$\begin{array}{c}\text { Productivity in the Use of } \\
\text { House }\end{array}$} & Time Productivity Used in Utilizing the House \\
\hline & & & Productivity of Use of the House \\
\hline
\end{tabular}




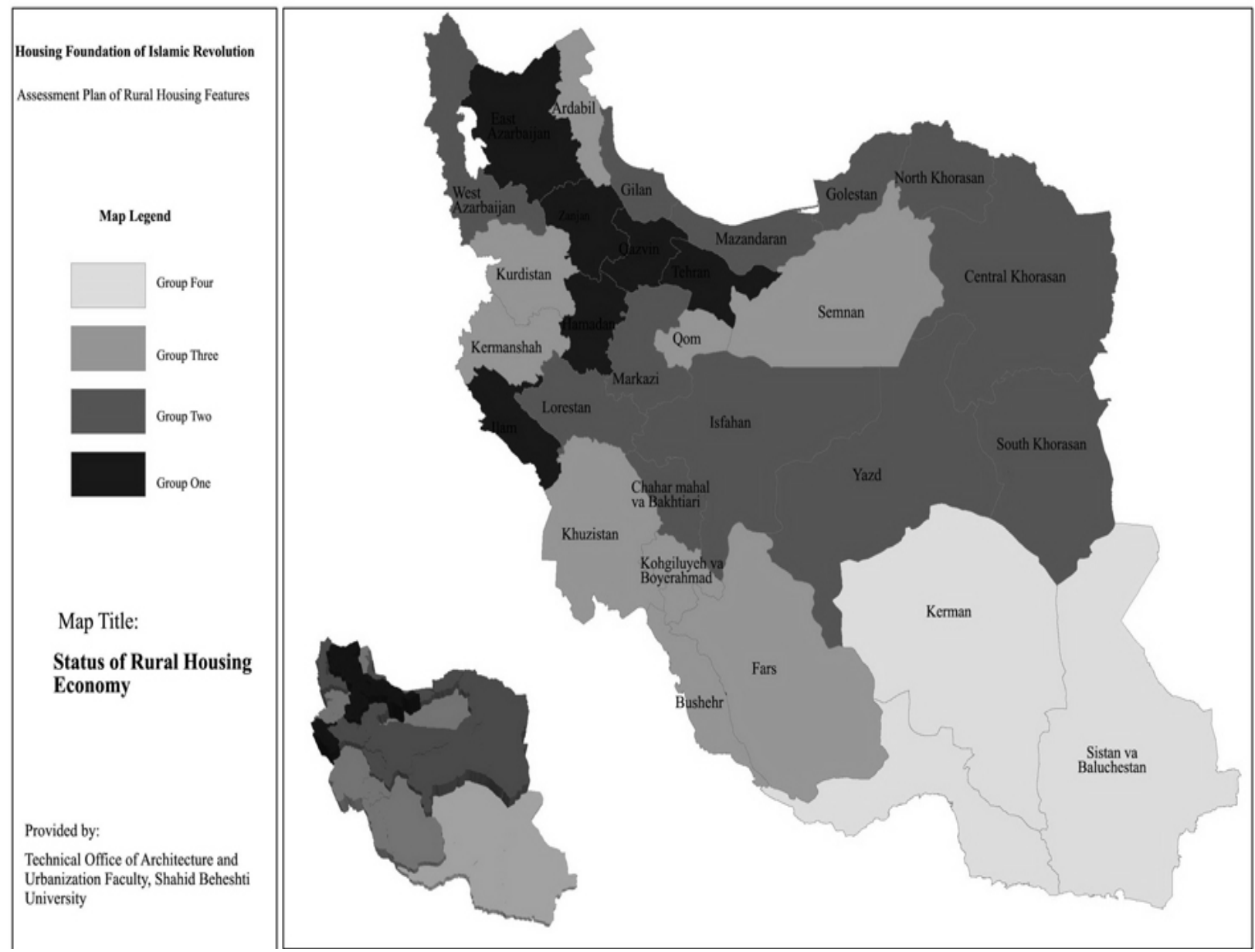

Figure 8. The Dimension of Economy and Livelihood in Rural Housing of Provinces in Iran

Table 3. Indexes, Indicators Level one and Level two and the Dimension of Availability of Welfare to Residential Units and the Relationship between Different Levels in Hierarchical Structure of the Plan

\begin{tabular}{|c|c|c|c|}
\hline Dimension & Index & Indicator Level one & Indicator Level two \\
\hline \multirow{17}{*}{$\begin{array}{l}\text { Availability of } \\
\text { Facilities and Ser- } \\
\text { vices (Welfare) in } \\
\text { Rural Housing }\end{array}$} & \multirow{9}{*}{$\begin{array}{l}\text { Availability of } \\
\text { Facilities to the } \\
\text { Residential Units }\end{array}$} & \multirow{3}{*}{$\begin{array}{c}\text { Availability of the Facilities to the } \\
\text { Residential Units }\end{array}$} & Availability of Infrastructural Facilities to Residential Units \\
\hline & & & Availability of Health Infrastructural Facilities to Residential Units \\
\hline & & & Availability of Welfare Facilities in Residential Units \\
\hline & & \multirow{2}{*}{ Safety Level of Residential Units } & Availability of lawfulness of Owning the Residential Units \\
\hline & & & Availability of Security of Occupation of Residential Units \\
\hline & & \multirow{4}{*}{$\begin{array}{l}\text { Level of Space Allocation in } \\
\text { Residential Units }\end{array}$} & The Amount of Floor Area of the Residential Units \\
\hline & & & The Amount of Area Dedicated to the Residential Units \\
\hline & & & Density of Number of People in a Housing Unit \\
\hline & & & Number of Rooms in a Residential Unit \\
\hline & \multirow{8}{*}{$\begin{array}{l}\text { Availability of } \\
\text { Facilities to the } \\
\text { Whole Villages }\end{array}$} & \multirow{4}{*}{$\begin{array}{c}\text { Availability of Services to the } \\
\text { Villages }\end{array}$} & Availability of Educational Services \\
\hline & & & Availability of Cultural-Religious Services \\
\hline & & & Availability of Health Services \\
\hline & & & Availability of Service and Commercial Facilities \\
\hline & & \multirow{3}{*}{$\begin{array}{l}\text { Availability of Infrastructural } \\
\text { Facilities to the Villages }\end{array}$} & Availability of Structural Facilities \\
\hline & & & Availability of Telecommunication Facilities \\
\hline & & & Availability of Roads \\
\hline & & $\begin{array}{c}\text { Availability of Political and Law } \\
\text { Enforcement Facilities }\end{array}$ & Availability of Political, Law Enforcement Facilities \\
\hline
\end{tabular}




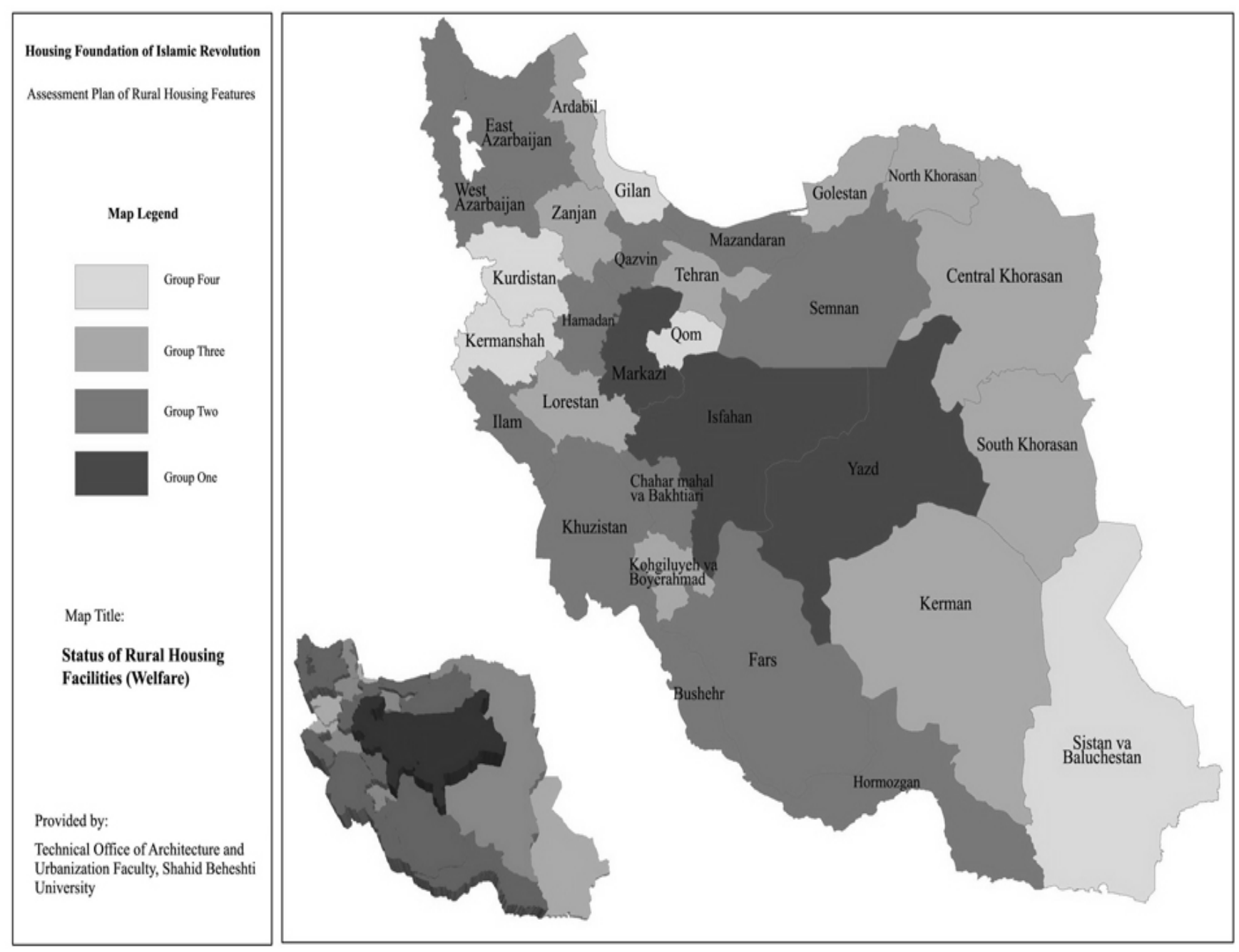

Figure 9. Comparison of the Dimension of Availability of Facilities (Welfare) to Rural Houses in Provinces of Iran

Table 4. Indexes and Level one and two Indicators of the Environmental Dimension and their Relation with Different Levels of Analysis in Hierarchical Structure of the Plan

\begin{tabular}{|c|c|c|c|}
\hline Dimension & Index & Level one Indicators & Level two Indicators \\
\hline \multirow{9}{*}{$\begin{array}{c}\text { Environmental } \\
\text { Dimension }\end{array}$} & \multirow{5}{*}{$\begin{array}{l}\text { Effect of Rural Resi- } \\
\text { dential Units on Eco- } \\
\text { system Destruction }\end{array}$} & \multirow{2}{*}{ Effect of Rural Residential Units on Waste Production } & $\begin{array}{c}\text { Use of Inappropriate Systems for Garbage } \\
\text { Disposal and Collection }\end{array}$ \\
\hline & & & $\begin{array}{c}\text { Use of Inappropriate Methods for Light } \\
\text { Sewage Disposal }\end{array}$ \\
\hline & & Effect of Residential Units on Air Pollution & $\begin{array}{l}\text { Effect of Rural Residential Units on Air } \\
\text { Pollution }\end{array}$ \\
\hline & & \multirow{2}{*}{$\begin{array}{l}\text { Effects of Residential Units on Destroying Natural } \\
\text { Resources }\end{array}$} & $\begin{array}{c}\text { The Expansion of Rural Residential Context } \\
\text { to Farmlands and Gardens }\end{array}$ \\
\hline & & & Use of Wood as Fuel \\
\hline & \multirow{4}{*}{$\begin{array}{l}\text { Compatibility of } \\
\text { Residential Units with } \\
\text { the Environment and } \\
\text { Nature }\end{array}$} & \multirow{2}{*}{$\begin{array}{c}\text { Effect of Architecture of Rural Residential Units on } \\
\text { Saving Energy }\end{array}$} & $\begin{array}{c}\text { Effects of the Number of House Openings } \\
\text { on Saving Energy }\end{array}$ \\
\hline & & & $\begin{array}{c}\text { Effect of Number of House Façades on } \\
\text { Saving Energy }\end{array}$ \\
\hline & & Effect of Rural Context on Saving Energy & $\begin{array}{c}\text { The Density of the Rural Residential Con- } \\
\text { text }\end{array}$ \\
\hline & & Vernacular Materials Usage in Rural Residential Units & $\begin{array}{c}\text { Use of Vernacular Materials in Residential } \\
\text { Units. }\end{array}$ \\
\hline
\end{tabular}




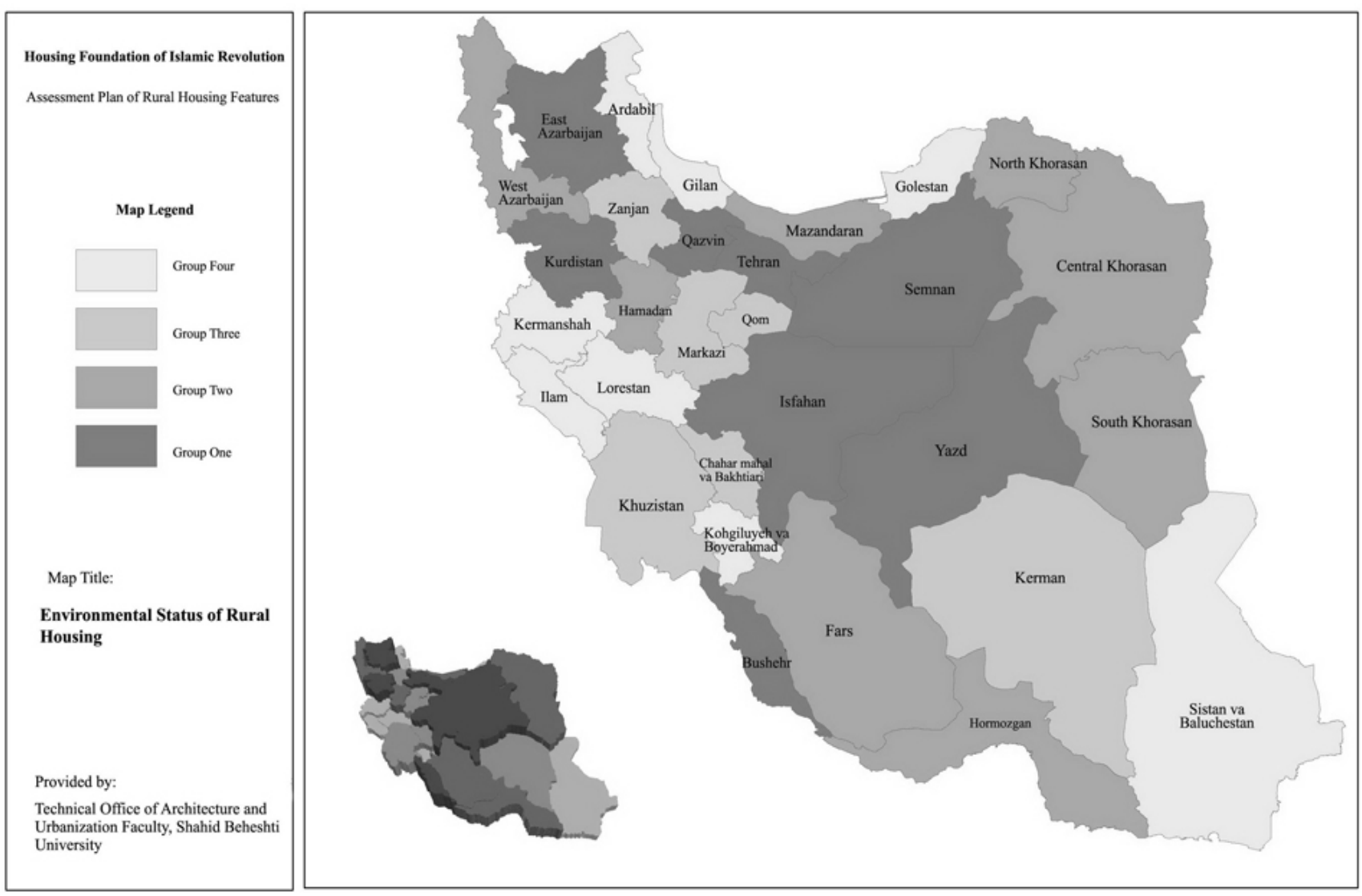

Figure 10. Comparsion of Environmental Dimension of Rural Houses in Provinces of Iran

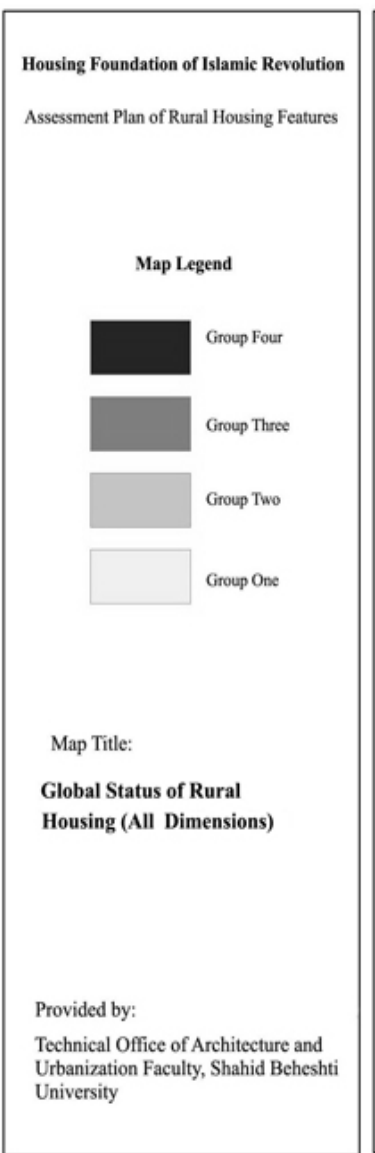

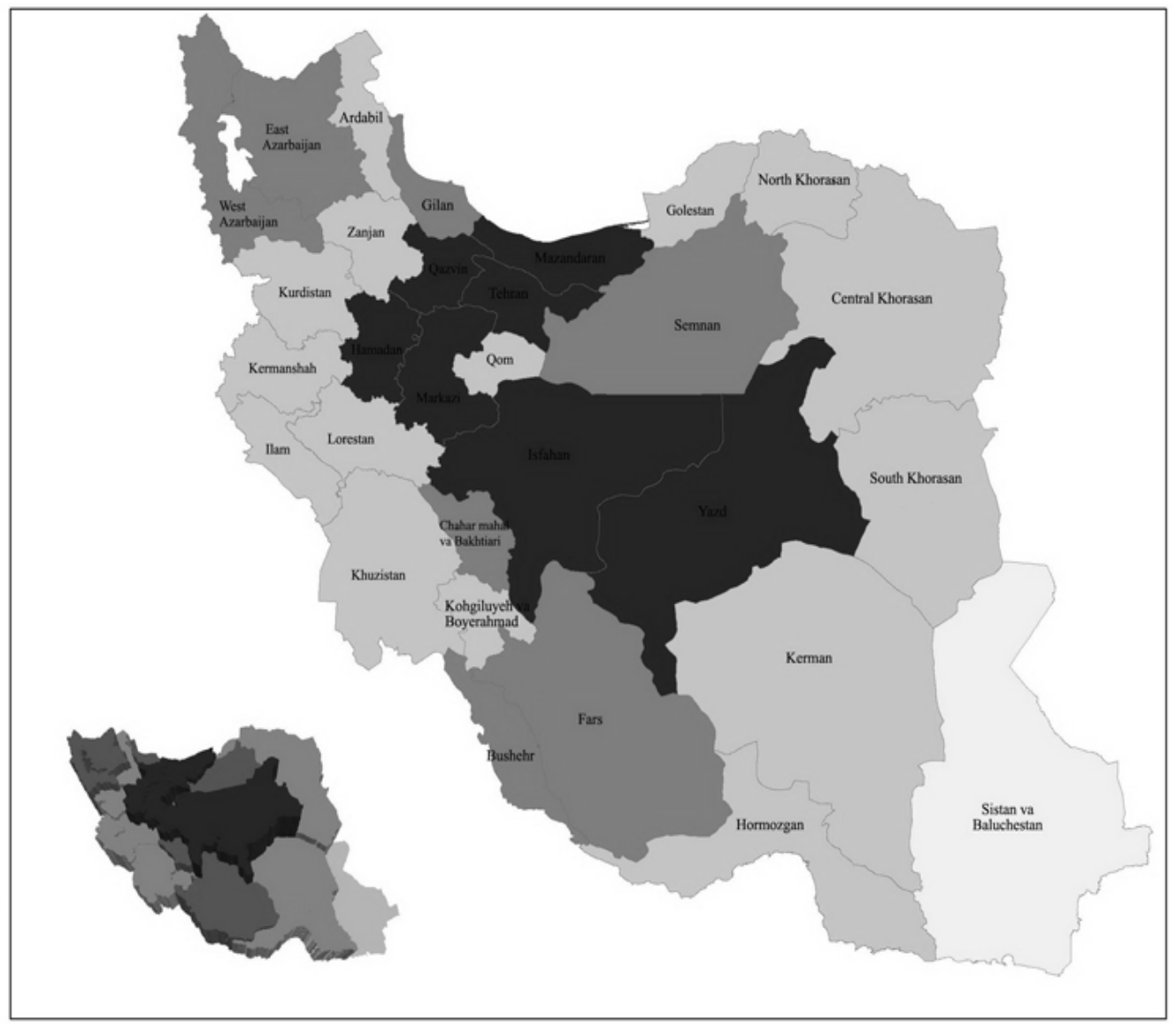

Figure 11. Overall Comparison of Rural Housing Status in Provinces of Iran 
The index for effect of residential units on destroying the ecosystem is obtained from integration of the following indicators: waste production, air pollution, destruction of natural resources and other related sampling data. Also, the index for the compatibility of residential units with nature and the environment index is obtained from indicators such as the effect of the architecture of the residential unit and rural context on saving energy, and the amount of vernacular materials used in rural houses. These indexes were analyzed according to their positive and negative effects and outcomes. First, the negative effects of housing on environment (e.g. inappropriate disposal of garbage and light and heavy sewage, destroying and polluting farmlands, gardens and natural resources and their damage to nature of the village) were analyzed.

Afterward, the positive effects of housing and context interaction with the rural-environment which could be accomplished through compatibility of rural housing with the surrounding nature was measured and discussed. In this viewpoint, issues such as compatibility of rural architecture and context with natural environment and use of renewable natural energy resources (like wind, sun, etc.) or adopting creative approaches for preventing or reducing the destructive effects of natural events (like harmful winds, storms, and harsh weather) were taken into account. Indexes and indicators shown in Table 4 present the Environmental dimension of rural housing. (Sartipipour 2007)

According to the results of analysis of environmental dimension, eight provinces fall into the first group, six provinces in the second group, six provinces in the third group and eight provinces in the fourth group. Geographical distribution of environmental conditions of rural housing is shown in Figure 10.

\subsection{Current General Status of Rural Housing}

Taking the four dimensions of Iranian rural houses under study and comparison shows that the quantity and quality of rural housing are not the same in different provinces. There's a significant and meaningful difference between rural houses in different provinces and this cannot be neglected by housing planners and decision-makers. However, from another viewpoint, the synthesis of the four dimensions of each province was considered in order to know the general conditions governing the status of rural housing. The results of the study show that, in total, only seven provinces are in a relatively better condition (first group). Seven provinces fall into the second group, thirteen in the third group and one single province in the fourth group due to the considerable distance of its criteria with those of the rest of the country. Figure 11 presents the overall status of rural housing in Iranian provinces in four levels. (Sartipipour 2007)

According to the above information, the best status of rural housing belongs to Yazd province in center of Iran and the most inappropriate conditions belongs to Sistan-vaBaluchestān. In terms of welfare, fabric and environmental dimensions, Yazd is placed in group one and in terms of economy and livelihood is in group two. Also, in terms of welfare and environmental dimensions, the province is in the best position in the country.

In comparison with other provinces of Iran, the southeastern province of Sistan-va- Baluchestān is placed in group four in terms of all four main dimensions. So, considering the housing features in this region, it is necessary to take into account all four dimensions of housing in this province within a separate program. (sartipipour 2005)

\section{Conclusions}

The rural architecture of Iran is an efficient and thoughtful example of the architecture in harmony with the everyday life of people, natural environments, and respect for nature. There are many positive principles, standards and fields in Iranian rural vernacular architecture that, if considered in new housing plans, can contribute to formation of a proper fabric. To name just a few of these principles, we may point to simplicity, functionality, use of modules in housing design, the humane attitude and vernacular technologies which grant them special features and can be a used as a valuable source for future rural housing with an emphasis on preserving its identity. Efforts at preserving or promoting these values in rural vernacular architecture will lead to the formation of a set of desirable settlements reliant upon natural environment as pattern for other regions.

On the other hand, socio-cultural changes resulting from modernization has changed the patterns for rural vernacular architecture in recent decades, and low cost of energy in Iran and use of new materials like steel and concrete has aggravated this trend. This issue has led to the degeneration and decline of the knowledge of rural vernacular architecture, the management of spaces and settlements, and the relevant principles which have been formed in the course of history. Neglecting vernacular technologies and ignorance toward the vernacular values and identity have led to a new pattern of housing seen everywhere; patterns that are sometimes in contradiction with vernacular patterns. They are neither a precise imitation of foreign patterns nor a proper application of new materials and technologies; they are neither in harmony with the environment nor are they compatible with the present needs of the residents.

Houses built in recent years are less compatible with eco systems, and usually the rural lifestyle in these houses is not taken into adequate account. Therefore, despite the increase in facilities and welfare equipment, rural houses are far from the standards of proper housing. Promotion of new patterns and copying them into rural life and housing, the shrink of land lots, and domination of urban standards in residential density, structures and techniques are problems affecting rural housing.

Comparison of the existing and past status of housing in Iranian villages, and analysis of indexes and indicators of rural housing of the 2003 sampling proves that one same solution for solving rural housing problems, which has been the dominant approach in housing programs, is not sufficient. 
Therefore, taking a systematic view toward the rural fabric and housing as a set of interrelated factors and principles which had obviously affected rural housing and environment in the past is quite essential. Thus, adopting a regional approach in housing development policies, compatible with provincial needs, is required. Accordingly, with regard to homogeneity and classification of provinces into four dimensions of housing and the sustainable values of vernacular architecture, a need for policy-makings and composing separate programs and patterns for the presented groupings is inevitable.

The Iranian method in determining the status of rural housing, which has provided the possibility of comparing provinces with each other and monitoring provincial changes in rural housing sector, is a method for assessment of rural housing and an appropriate solution which could also be used as a guideline for other countries.

\section{REFERENCES}

[1] Budget and Planning Organization. Statistical yearbook of Iran. Budget and Planning Organization. Tehran, Iran, 1993.

[2] Central Bank of Islamic Republic of Iran. Directives for statistical plans. Bureau of Economical Statistics. Tehran, Iran, 1995.

[3] Housing Foundation of Islamic Republic of Iran (HFIRI), Census program of studying features of rural housing (plus appendixes). Tehran, Iran, 2003.

[4] Housing Foundation of Islamic Republic of Iran (HFIRI), Master plan for rural housing: the plan for preparing backup documents and rural housing plan in the Fourth Program. Deputy of Housing and Reconstruction. Tehran, Iran, 2005.

[5] Housing Foundation of Islamic Republic of Iran (HFIRI), Performance Report of Rural Housing in 2008. Bureau of
Rural Housing Renovation and Reconstruction. Tehran, Iran, 2008.

[6] Housing Foundation of Islamic Republic of Iran (HFIRI), Performance Report of 2009. Deputy of Rural Development. Tehran, Iran, 2009.

[7] Ministry of Housing and Urban Development (MHUD), The comprehensive housing plan, analytical document, study results. Tehran, Iran, 2006.

[8] Sartipipour, M. (2005). Rural housing architectural indicators in Iran. Journal of Fine Arts, 22.

[9] Sartipipour, M. (2007a). 'Rural Housing in five years Development Programs', Journal of Fine Arts, 27.

[10] Sartipipour, M. Physical pathology of Iranian vernaculars architecture: towards a preferred settlements. Tehran: Shahid Beheshti University, Housing Foundation of Islamic Revolution \& Hooshmand Press. Tehran, Iran, 2009.

[11] Sartipipour, M. et al. Assessment and analysis of rural housing features (2003 Sampling). Tehran: Shahid Beheshti University \& Housing Foundation of Islamic Republic of Iran. Tehran, Iran, 2007b.

[12] Statistical Center Of Iran (SCI), The nomads' socio-economic features statistics project, document collection for management of social census. Tehran, Iran, 1990.

[13] Statistical Center of Iran (SCI), Glossary of definitions and terms used in statistical plans and reports. Tehran, Iran, 1995.

[14] Statistical Center of Iran (SCI), General Census of the Population and Housing in 2006. Tehran, Iran, 2006.

[15] Taleb, Mehdi. Rural Management in Iran, Tehran: Tehran University Publications. Tehran, Iran, 1998.

[16] Zargar, A. (1997). Common features of Iranian architecture. Sofe Journal, 25.

[17] Zargar, A. An Introduction to Rural Architecture of Iran. Tehran: Shahid Beheshti University Publications. Tehran, Iran, 1999.

\footnotetext{
i The original Persian Word is siah-chador

ii The original Persian word is Alachigh meaning a shady leafy shelter
} 